\title{
SEARCHING FOR INVASIVE ALIENS: A CASE STUDY FROM ZA \& ZAHO HERBARIUM COLLECTIONS
}

\section{Tihana Vilović ${ }^{1}$, Vedran Šegota ${ }^{2 *}$, Kristina Bilić $^{3} \&$ Toni Nikolić ${ }^{4}$}

1'Department of Pharmaceutical Botany, Faculty of Pharmacy and Biochemistry, University of Zagreb, Schrottova 39, 10000 Zagreb, Croatia

${ }^{2}$ ZA \& ZAHO herbarium collections, Division of Botany, Department of Biology, Faculty of Science, University of Zagreb, Marulićev trg 20/II, 10000 Zagreb, Croatia

${ }^{3}$ Independent Researcher, Velika Gorica, Croatia

${ }^{4}$ Division of Botany, Department of Biology, Faculty of Science, University of Zagreb, Marulićev trg 12, 10000 Zagreb, Croatia

Vilović, T., Šegota, V., Bilić, K. \& Nikolić, T.: Searching for invasive aliens: a case study from ZA \& ZAHO herbarium collections. Nat. Croat., Vol. 29, No. 1., 99-108, 2020, Zagreb.

Herbarium collections are the most reliable source of historical data available with respect to alien plants. A review of the ZA and ZAHO herbarium collections revealed the presence of as many as 1,152 specimens of invasive alien plant species (IAS), belonging to 70 plant taxa. The extent of sampling invasive taxa was not constant over time; a high $67 \%$ of the collection has been collected since the Second World War, with the collection peaking between 1900 and 1920, between 1960 and 1970 and in the years after 2010. Herbarium records of 17 taxa revealed that they first appeared in Croatia much earlier than was known from the literature so far. In order to enhance its public availability, the collection of IAS studied has been digitised and published in the virtual herbarium.

Key words: botanical collections, digitisation, Flora Croatica Database, IAS, invasion, virtual herbarium

Vilović, T., Šegota, V., Bilić, K. \& Nikolić, T.: U potrazi za invazivnim stranim svojtama: studija slučaja iz herbarijskih zbirki ZA \& ZAHO. Nat. Croat., Vol. 29, No. 1., 99-108, 2020, Zagreb.

Herbarijske zbirke predstavljaju najpouzdanije povijesne izvore podataka o stranim biljnim vrstama. Unutar zbirki ZA i ZAHO pronađena su ukupno 1152 herbarijska lista sa 70 invazivnih biljnih svojti. Intenzitet sakupljanja invazivnih svojti nije bio konstantan kroz vrijeme, čak 67 \% zbirke sakupljeno je nakon Drugog svjetskog rata, a vrhunci sakupljanja bili su od 1910. do 1920., od 1960. do 1970., te nakon 2010. godine. Herbarijski primjerci 17 vrsta dokazuju njihovu prvu pojavu u Hrvatskoj mnogo prije nego što je dosad bilo poznato iz literature. Kako bi se povećala javna dostupnost zbirke, svi primjerci su digitalizirani i objavljeni u virtualnom herbariju.

Ključne riječi: botaničke zbirke, digitalizacija, Flora Croatica Database, invazivne strane vrste, invazija, virtualni herbarij

\section{INTRODUCTION}

Natural history collections and especially herbarium collections are a rich source of ecological data, given that there are more than 387 million specimens in 3,095 active

\footnotetext{
* corresponding author: vedran.segota@biol.pmf.hr
} 
herbaria world-wide that document the earth's vegetation for the past 400 years and thus can be used to study diverse questions (THIERs, 2020). Stored plant specimens are usually well preserved, so any identification error can be corrected afterwards; moreover, they include detailed information about sampling locations, dates and the associated habitats (Delisle et al., 2003). Implementing the digitising techniques in herbaria worldwide, specimens become more accessible and thus more valuable, especially if the digitised specimen data are combined with other data, environmental or genetic, for instance (Soltis et al., 2018). As well as for their primary purposes in taxonomy and systematics, herbarium collections can now also be used for the analysis of a wide range of environmental topics, depending on the types of data that can be obtained from specimens. Utilizing information on meta-data (date and location), phenotype, phenology, molecular data and biotic interactions of collected herbarium specimens, in recent years, several new approaches have emerged, such as studies of invasions, habitat change, climate change and pollution (LANG et al., 2019).

However, there are some limitations of which researchers must be aware when using herbarium records as a basis for their analysis. Some biases that may occur include unequal collecting efforts over time, incorrect identification, poor location information, disproportionally represented data, accessibility of sampling sites, seasonality of plant growth, intensity of floristic research in a given area and the floristic interests of collectors (Crawford \& Hoagland, 2009; Delisle et al., 2003; Antunes \& Schamp, 2017). Also, collections often concentrate on common or particularly interesting species which, depending on the collectors, can change over time (taxonomic bias) (LANG et al., 2003). In addition, some groups of species, such as aliens and garden escapees, are recorded less consistently than native species, (Delisle et al., 2003). Furthermore, large sized taxa and those that can cause health problems might be underrepresented in herbarium collections (ANTUNES \& SCHAMP, 2017).

Invasive alien species (IAS) are species that are not native to a particular region, were introduced through human activity, have reached the final stage of invasion process (which includes three stages: casual, naturalized and invasive) and have the capacity to spread, overcoming dispersal barriers (PY̌̌EK et al., 2008). IAS are nowadays considered one of the greatest threats to flora biodiversity and its conservation worldwide. Floras of many European regions are losing their diversity due to introduced alien species which causes taxonomic and phylogenetic homogenization (WINTER et al., 2009).

The first efforts towards the implementation of the European Strategy on IAS (GENOvEsi \& SHINe, 2004) regarding vascular flora started with the preliminary report listing 58 taxa considered as invasive in the Croatian flora (Dobrović et al., 2006). Moreover, a special module for "allochthonous" (alien, non-native) plants was developed within the Flora Croatica Database (hereafter: FCD), intended for data collecting and data dissemination (Nikolić et al., 2013; Nikolić, 2020). The standardisation of the terminology and criteria for alien flora in Croatia was proposed (Miтić et al., 2008) and an upgraded preliminary check-list of IAS was made, containing 64 taxa (Boršić et al., 2008). The study of Croatian alien flora has been intensified in recent years (e.g. Vuкоvić et al., 2010; 2018; Nikolić et al., 2013; Alegro et al., 2016; Rimac et al., 2018), as the FCD is continuously updated with new findings and the list of alien species revised. Currently there are 625 alien plant taxa in Croatia, which comprise $12.4 \%$ of the total flora, out of which 76 are considered invasive. Among IAS, therophytes predominate as a life form, with 53.2\% (NiкоLіć, 2013), while the analysis of geographic origin showed that majority of them originated from the Americas (Boršić et al., 2008). 
Several studies have shown the significant strength of herbarium records in plant invasion studies (PyšEK \& Prach, 1993; Minulka \& PyšEK, 2001; Mandák et al., 2004; Wu et al., 2004; FuENTEs et al., 2008), although there have also been concerns about the biases and gaps that this information may contain (Funk \& Richardson, 2002; Moerman \& Estabrook, 2006; Crawford \& Hoagland, 2009) and the consequences these may have on policies for managing and controlling invasive alien plants (Aıкıо et al., 2010). Nevertheless, herbarium records are, at present, the main and most reliable source of historical information available with respect to alien plants (FuENTEs et al., 2008).

The main goals of our study were to (1) determine the presence of IAS within the ZA \& ZAHO herbaria, (b) digitise the collections in order to provide public availability and (c) examine whether the collections contain spatio-temporal data on the arrival of invasive aliens in the country.

\section{MATERIALS AND METHODS}

Currently, Croatia has 12 officially registered herbarium collections (THIERs, 2020). In our search for invasive plants we were focused on the two oldest and largest ones: Herbarium Croaticum (ZA), established in 1880, with around 230,000 specimens and Herbarium Ivo and Marija Horvat (ZAHO) founded in 1918, with around 72,000 specimens (REŠETNIK \& ŠEGOTA, 2020). Herbarium specimens of IAS, as defined in NiKOLIĆ (2020), were dusted off, translocated to new herbarium sheets and mounted, prior to being digitised. The basic metadata from the herbarium labels, including taxon name, locality, habitat, collecting date, collector(s) and identifier(s) were input to the FCD. Moreover, the original localities of collecting were updated and geo-referenced in the GIS environment. The greatest effort had to be made in attempts to read the original handwriting, which was particularly difficult for the oldest specimens, written in several languages. The number of specimens representing each taxon, number of collected specimens within discrete time intervals (decades), main collectors and country of specimen origin were analysed. Furthermore, we checked the literature data for each invasive alien taxon within the FCD (containing almost 10,000 literature references since 1730) in search of information on their first appearance in Croatia, in order to compare it with the first collected herbarium specimen.

\section{RESULTS AND DISCUSSION}

The taxonomic analysis of the material from the ZA and ZAHO collections revealed as many as 1,152 herbarium specimens, belonging to 70 plant taxa (Fig. 1) of 27 plant families. The greatest number of specimens were found for Veronica persica Poir. (90), Euphorbia prostrata Aiton (54), Sorghum halepense (L.) Pers. (46), Erigeron anuus (L.) Pers. (44) and Conyza canadensis (L.) Cronquist (41).

Five invasive taxa were not found in the examined herbaria, namely Amaranthus blitoides S. Watson, Conyza sumatrensis (Retz.) E. Walker, Epilobium ciliatum Raf., Opuntia ficus-indica (L.) Miller and Reynoutria sachalinensis (F. S. Petrop.) Nakai in T. Mori., all of them being previously recorded in the literature and in observations, but for specific reasons not collected. Such biases in herbarium collections may exist with respect species that have, for example, large characters (ANTUnes \& SснAмp, 2017), such as, in our case, in Opuntia ficus-indica, with its large and thick cladodes, and Conyza sumatrensis, with its rather tall habitus, which can pose problems with pressing and mounting. In addition, C. sumatrensis was largely unrecognised as such since the late 80 s due to its similarities 

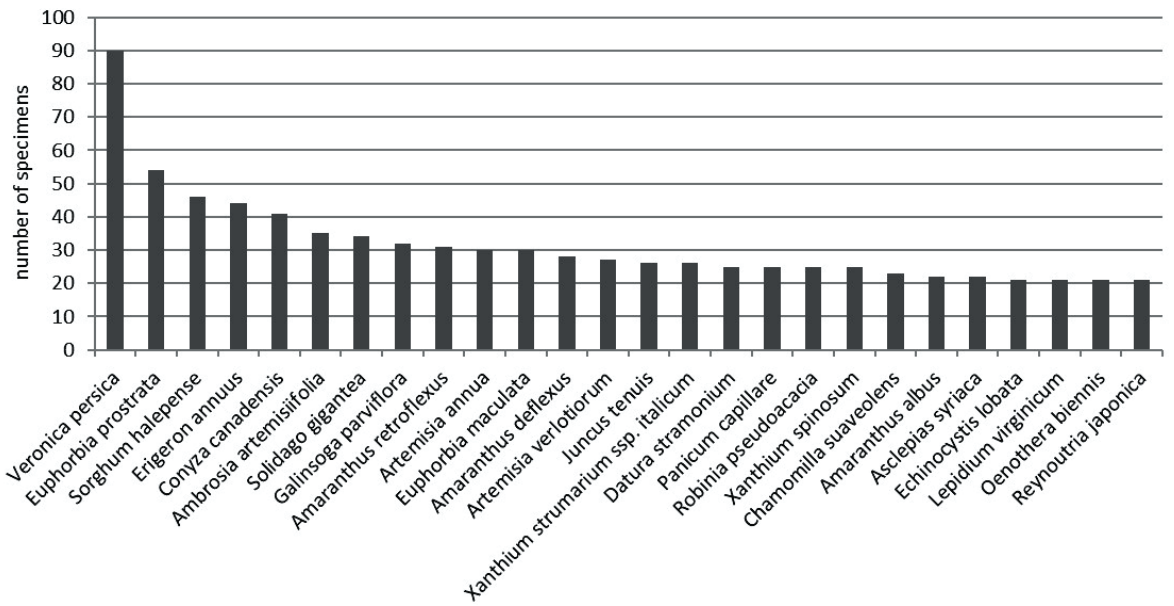

Fig. 1. The most frequent invasive alien taxa within ZA \& ZAHO collections

with C. bonariensis. Thus, the first record in Croatia was made as late as in 2004 (Milović, 2004). As for Epilobium ciliatum and Reynoutria sachalinensis, we assume that they were not collected due to their generally rare occurrence in Croatia.

In total, contributing to the collections examined were 88 collectors, among whom the most prolific contributors are Ljerka Marković (1932-), Vedran Šegota (1982-) with co-collectors, and Ljudevit Rossi (1850-1932) (Fig. 2).

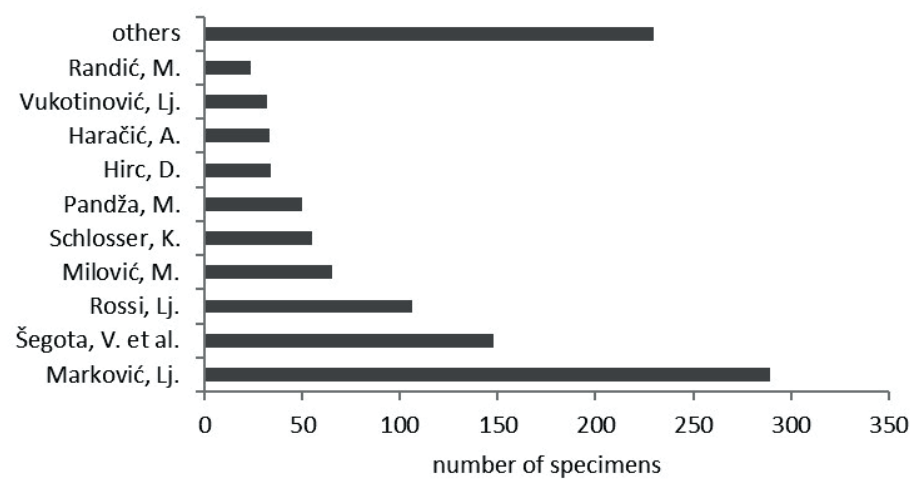

Fig. 2. The most fruitful collectors of invasive plant taxa within ZA \& ZAHO collections

Invasive taxa were not sampled to a consistent extent over time. The oldest specimens date back to 1851 (Conyza canadensis (L.) Cronquist, Erigeron anuus (L.) Pers. and Phytolacca americana L.), while the average age of specimens is 83 years. However, as much as $67 \%$ of the collection has been collected since the Second World War. The first peak from 1900 to 1920 is related to the collection of the famous Croatian botanist 
Ljudevit Rossi. The second peak from 1960 to 1970 can be ascribed to the effort of Professor Ljerka Marković, who was dedicated to research into allochthonous plants and discovered many invasive species in Croatia (Ilijanić, 2004), whereas the third peak in the years after 2010 includes the most recent studies of invasive alien flora in Croatia during the last ten years (Fig. 3). Similarly, a significant increase in IAS findings in the early 1960s has been already noticed while analysing data from FCD (Nikolić et al., 2013). Collecting activity in both collections was very weak in the period between the two World Wars. The largest parts of the ZAHO collection were collected in the 1910s and 1940s, reflecting the fieldwork of Professor Ivo Horvat.

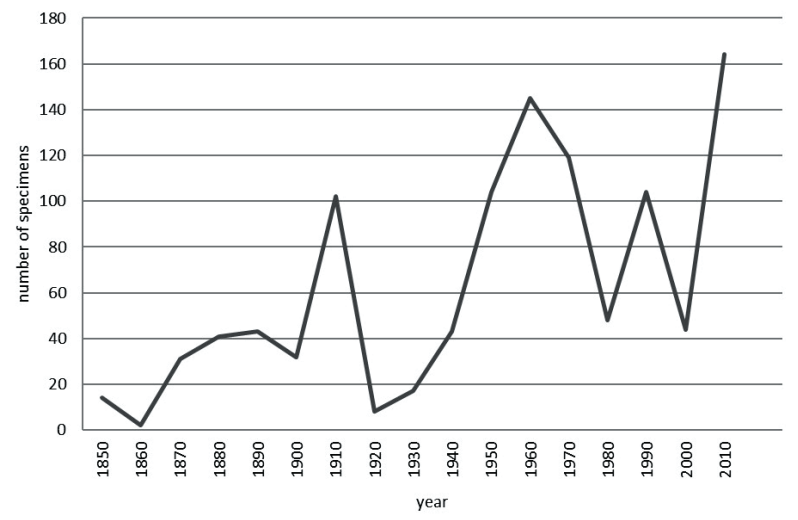

Fig. 3. Temporal distribution of specimens of invasive plant taxa within ZA \& ZAHO collections

Regarding the country of origin, the vast majority are from Croatia (93\%) and neighbouring Slovenia (5\%), while the rest originate from Serbia, Montenegro, Bosnia \& Herzegovina and Poland. Since the level of inaccuracy in herbarium data in terms of geo-precision was rather high in previous assessments (NiкоLić et al., 2013), special attention was given to correctly interpreting all the localities from herbarium labels.

Previous studies addressed the problem of dating the first appearance of invasive species in Croatia, since the quality of such information varies considerably (Nikolić et al., 2013). With respect to the first literature records, we observed 17 taxa occurring much earlier in the inspected herbaria. For 11 of them the temporal gap between the first herbarium and the literature record is less than 50 years, for three taxa from 50 to 100 years, whereas for three taxa the first literature mention appeared more than 100 years after their first herbarium collection (Fig. 4). There was a similar report for alien plants in Chile (Fuentes et al., 2013) and Zimbabwe (MAroyi, 2012) where the earliest recorded dates of the majority of alien plants have been found in herbaria. With $8 \%$ of specimens lacking information about the collecting date, we dated some taxa according to the life span of the related collector, using the year of their death as the latest possible date when the specimen could have been collected, unlike the analysis of CRAWFORD \& HoAgLAND (2009) in which herbarium specimens lacking a specific collection date were excluded. For example, the earliest collected herbarium sheet of Elodea canadensis Michx. [ZA12400] was that of a specimen of Schlosser which did not have a collecting date; as Schlosser died in 1882, we used that year as the latest possible date of collecting. 


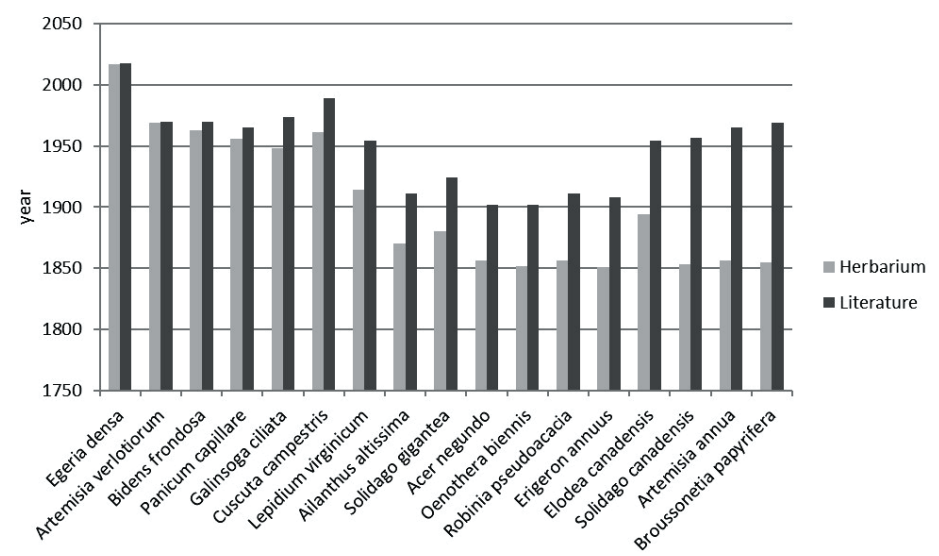

Fig. 4. First records of invasive plant taxa in Croatia in ZA \& ZAHO herbaria vs. literature

Broussonetia papyrifera (L.) Vent. was first collected in 1855 - assigned as cultivated [ZA15928] and in 1887 - not assigned as cultivated [ZA15929], while it was published in the literature a full 114 years later (RAUš, 1969). The first herbarium record of Artemisia annua L. was collected in 1856 [ZA45107] and mentioned in the literature 109 years later (MARKović-Gospodarić, 1965). Furthermore, Solidago canadensis L. was collected for the first time in 1880 [ZA1633], while the first literature data appeared 104 years later (Bevilacqua, 1957) (Fig. 5).

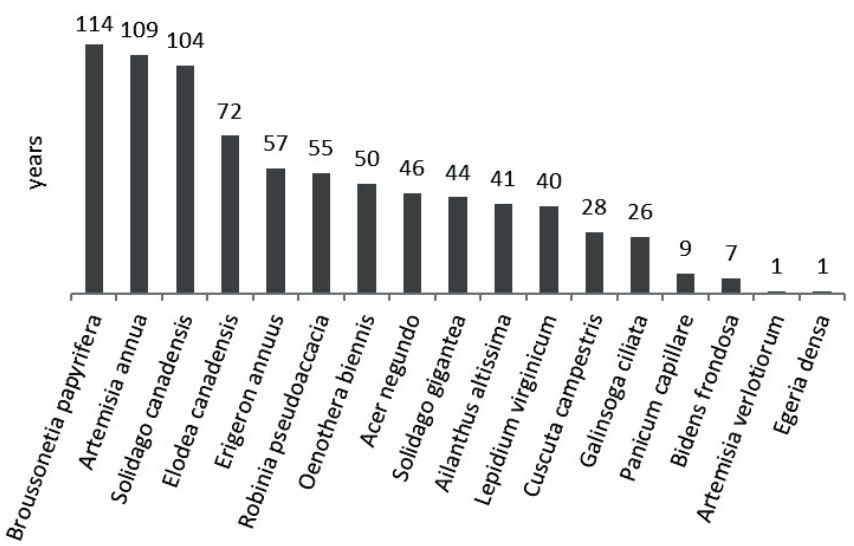

Fig. 5. Temporal gaps (in years) between first ZA \& ZAHO herbarium and literature records of invasive plant taxa in Croatia

In many cases it was difficult to clearly distinguish between the spontaneous and cultivated specimens of a certain taxa, considering the parsimony of the information on the herbarium labels, but we did not exclude cultivated ones, unlike CRAwFORD \& Hoagland (2009). For the following IAS species which are commonly cultivated, besi- 
des the already mentioned B. papyrifera, here are the earliest known literary accounts for specimens in culture and presumably outside of it, respectively: Acer negundo L. 1856 [ZA15726] and 1879 [ZA15725], Ailanthus altissima (Mill.) Swingle - 1870 [ZA15740] and 1876 [ZA15738], Oenothera biennis L. - 1852 [ZA16183] and 1889 [ZA16185] and Robinia pseudoaccacia L. - 1856 [ZA1856] and 1882 [ZA16307].

There is also an interesting case of the invasive Panicum capillare L.; it was determined that some specimens so identified are actually of Panicum riparium $\mathrm{H}$. Scholz (KIRÁly \& Alegro, 2015). This species was previously reported as a new invader, but it is an overlooked, long-established taxon in central Europe. So, as the oldest specimens of $P$. capillare from the $19^{\text {th }}$ century have turned out to be $P$. riparium, the oldest example from a herbarium is now dated to 1956 [ZA16207], while the first literature record appeared in Hundozi (1965).

While studying temporal and spatial dynamics of alien species, one must be aware that most of the species were not invasive on their first appearance in new areas and a certain period of time must pass in order for the species to come into the expansion phase (LAmbrinos 2001). Why some non-native species become invasive and the source of the variation in time between arrival and the onset of invasive expansion are poorly understood (ANTUnes \& Schamp, 2017). However, the arrival of newcomers at a certain reproductive capacity must increase their competitiveness. The spatio-temporal study of alien naturalisation and invasive expansion based on ZA and ZAHO collections will be part of a future analysis.

As shown in our study, herbaria are, along with the literature records, essential for the inventory of introduced species, which can serve for future management strategies. However, despite being a large repository of historical and geographical information, herbaria are still underutilized institutions (CRAWFORD et al., 2009). Moreover, they are globally becoming threatened to a certain extent, since plant collecting is in decline and has become somewhat old-fashioned (PrATHer et al., 2004; CRAwFord et al., 2009; MoLNÁR et al., 2012b). This trend is in general compounded by a reduced interest in plant taxonomy (WortLey et al., 2002), resulting in the elimination of herbaria at some universities in recent years (CRAWFORD et al., 2009). These tendencies are worrisome, since major gaps in data will seriously hamper future historical reconstructions of biological invasions, and consequently complicate the understanding and modelling of such processes (Delisle et al., 2003). Invasive plants are, however, excluded from this trend, as shown in our study, since they have become a subject of interest rather recently.

\section{ACKNOWLEDGMENTS}

This research was financially supported by Croatian Ministry of Environmental Protection and Energy through co-funding of Flora Croatica Database as a part of Information System of Nature Protection (ISZP).

Received January 12, 2020

\section{REFERENCES}

Aikio, S., Duncan, R. \& Hulme, P., 2010: Herbarium records identify the role of long-distance spread in the spatial distribution of alien plants in New Zealand. Journal of Biogeography 37, 1740-1751.

Alegro, A., Šmgota, V. \& Vuković, N., 2016: Rasprostranjenost invazivnih biljnih vrsta i mjere njihova suzbijanja u zoni korištenja Parka prirode Medvednica. Croatian Botanical Society, Zagreb. 
Antunes, P. M. \& Schamp. B., 2017: Constructing standard invasion curves from herbarium data - Toward increased predictability of plant invasions. Invasive Plant Science and Management 10, 293-303.

Bevilacqua B., 1957: Revizija studentskog herbara. Diplomski rad, Prirodoslovno-matematički fakultet, Sveučilište u Zagrebu, Zagreb, 1-106.

Boršić, I., Milović, M., Dujmović, I., Bogdanović, S., Cigić, P., Rešetnik, I., Nikolić, T. \& Mitić, B., 2008: Preliminary check-list of invasive alien plant species (IAS) in Croatia. Natura Croatica 17(2), 55-71.

Crawford, P. H. C. \& Hoagland, B. W., 2009: Can herbarium records be used to map alien species invasion and native species expansion over the past 100 years? Journal of Biogeography 36, 651-661.

Delisle, F., Lavoie, C., Jean, M. \& Lachance, D., 2003: Reconstructing the spread of invasive plants: taking into account biases associated with herbarium specimens. Journal of Biogeography 30, 1033-1042.

Dobrović, I., Boršıć, I., Milović, M., Bogdanović, S., Cigić, P., Rešetnik, I., Nikolić, T. \& Mitić, B., 2006: Invasive alien species in Croatia-preliminary report. In: Besendorfer, V., \& KlobučAr, G: Book of abstract of the 9th Croatian Biological Congress with International Participation, Zagreb. Croatian Biological Society, 146-147.

Fuentes, N., Pauchard, A., Sánchez, P., Esquivel, J. \& Marticorena, A., 2013: A new comprehensive database of alien plant species in Chile based on herbarium records. Biological Invasions 15, 847-858.

Fuentes, N., Ugarte, E., KüHN, I. \& Klotz, S., 2008: Alien plants in Chile: inferring invasion periods from herbarium records. Biological Invasions 10, 649-657.

FunK, V. A. \& Richardson, K. S., 2002: Systematic data in biodiversity studies: use it or lose it. Systematic Biology 51, 303-316.

Genovesi, P. \& Shine, C., 2004: European Strategy on Invasive Alien Species. Nature and Environment 137, Council of Europe Publishing. http://www.coe.int/t/dg4/cultureheritage/conventions/Bern/TPVS/ sc24_inf01_en.pdf, accessed on 1 January 2020.

Hundozi B., 1965: Fitocenološka istraživanja nizinskog područja između Sesveta i Dugog Sela u široj okolici Zagreba. Magistarski rad, Prirodoslovno-matematički fakultet, Sveučilište u Zagrebu, Zagreb, 1-68.

ILIJANić, I., 2004: Professor Ljerka Marković - Croatian botanist. On the occasion of her seventieth birthday. Acta Botanica Croatica 63(2), 206-211.

KirÁly, G. \& Alegro, A., 2015: Re-evaluation of the Panicum capillare complex (Poaceae) in Croatia. Acta Botanica Croatica 74(1), 173-179.

Lambrinos, J. G., 2001: The expansion history of a sexual and asexual species of Cortaderia in California, USA. Journal of Ecology 89, 88-98.

Lang, P. L. M., Willems, F. M., Scheepens, J. F., Burbano, H. A. \& Bossdorf, O., 2019: Using herbaria to study global environmental change. New Phytol. 221(1), 110-122.

Mandák, B., PyšEK, P. \& KateǩIna, B., 2004: History of the invasion and distribution of Reynoutria taxa in the Czech Republic: a hybrid spreading faster than its parents. Preslia 76, 15-64.

Marković-Gospodarić LJ., 1965: Prilog poznavanju ruderalne vegetacije kontinentalnih dijelova Hrvatske. Acta Botanica Croatica 24, 91-136.

MAroyI, A., 2012: The casual, naturalised and invasive alien flora of Zimbabwe based on herbarium and literature records. Koedoe - African Protected Area Conservation and Science 54(1), 30-36.

MinulKa, S. \& PYšEK, P., 2001: Invasion history of Oenothera congeners in Europe: a comparative study of spreading rates in the last 200 years. Journal of Biogeography 28, 597-609.

Milović M., 2004: Naturalised species from the genus Conyza Less. (Asteraceae) in Croatia. Acta Botanica Croatica 63(2), 147-170.

Mitić, B., Boršić, I., Dujmović, I., Bogdanović, S., Milović, M., Cigić, P., Rešetnik., I. \& Nikolić, T., 2008: Alien flora of Croatia: proposals for standards in terminology, criteria and related database. Natura Croatica 17(2), 73-90.

Moerman, D. E. \& Estabrook, G. F., 2006: The botanist effect: counties with maximal species richness tend to be home to universities and botanists. Journal of Biogeography 33, 1969-1974.

Molnár, A.V., Takács, A., Horváth, O., Vojtkó, A.E., Király, G., Sonkoly, J., Sulyok, J. \& Sramkó, G., 2012a: Herbarium Database of Hungarian Orchids I. Methodology, dataset, historical aspects and taxa. Biologia 67(1), 79-86.

Nikolić, T. (ed.), 2020: Flora Croatica Database. On-Line (http://hirc.botanic.hr/fcd). Division of Botany, Faculty of Science, University of Zagreb, accessed on 1 January 2020.

Nikolić, T., Mitić, B., Milašınović. \& Jelaska, S. D., 2013: Invasive alien plants in Croatia as a threat to biodiversity of South-Eastern Europe: Distributional patterns and range size. Comptes Rendus Biologies 336, 109-121. 
Prather, L. A., Alvarez-Fuentes, O., Mayfield, M. H. \& Ferguson, C. J., 2004: The decline of plant collecting in the United States: a threat to the infrastructure of biodiversity studies. Systematic Botany 29, 15-28.

PYšEK, P. \& PRACH, K., 1993: Plant invasion and the role of riparian habitats: a comparison of four species alien to central Europe, Journal of Biogeography 20, 413-420.

Pyšek, P., Richardson, D. M., Pergl, J., Jarošík, V., Sixtová Z. \& Weber, E., 2008: Geographical and taxonomic biases in invasion ecology. Trends in Ecology and Evolution 23(5), 237-244.

RAUŠ Đ., 1969: Autohtona i alohtona dendroflora šire okolice Vukovara. Šumarski list: znanstveno-stručno i staleško glasilo Hrvatskoga šumarskog društva 93(5-6), 185-209.

ReŠETniK, I. \& ŠEgOTA, V., 2020: Virtual herbarium ZA \& ZAHO. On-line (http://herbariumcroaticum.biol. pmf.hr). Division of Botany, Faculty of Science, University of Zagreb, accessed on 1 January 2020.

Rimac, A., Stanković, I., Alegro, A., Gottstein, S., Koletić, N., Vuković, N., Šegota, V. \& Žižić-Nakić, A., 2018: The Brazilian Elodea (Egeria densa Planch.) invasion reaches Southeast Europe. Bioinvasions Records 7(4): 381-389.

Soltis, P. S., Nelson, G. \& JAmEs., S. A., 2018. Green digitization: Online botanical collections data answering real-world questions. Applications in Plant Sciences 6(2), 1-4.

Thiers B., 2020: Index Herbariorum. On-Line (http://sweetgum.nybg.org/ih/) A global directory of public herbaria and associated staff. New York Botanical Garden's Virtual Herbarium, accesses on 1 January 2020.

Vuković, N., Bernardić, A., Nikolić, T., Hršak, V., Plazibat, M. \& Jelaska, S. D., 2010: Analysis and distributional patterns of the invasive flora in a protected mountain area - a case study of Medvednica Nature Park (Croatia). Acta Societatis Botanicorum Poloniae 79(4), 285-294.

Vuković, N., Šmgota, V., Alegro, A., Koletić, N., Rimac. A. \& Dekanić, S., 2018: "Flying under the radar" - How misleading distributional data lead to wrong appreciation of knotweeds invasion (Reynoutria spp.) in Croatia. Bioinvasions records 8(1), 175-189.

Winter M., Schweiger, O., Klotz, S., Nentwig, W., Andriopoulos, P., Arianoutsou, M., Basnou, C., Delipetrou, P., Didžiulis, V., Hejda, M., Hulme, P. E., Lambdon, P. W., Pergl, J., Pyšek, P., Roy, D. B. \& KüHN, I., 2009: Plant extinctions and introductions lead to phylogenetic and taxonomic homogenization of the European flora. Proceedings of the National Academy of Sciences of the United States of America 106: 21721-21725.

Wortley, A. H., Benet, J. R. \& Scotland, R. W., 2002: Taxonomy and phylogeny reconstruction: two distinct research agenda in systematic. Edinburgh Journal of Botany 59, 335-349.

Wu, S. H., Hsieh, C. F., Chaw, S. M., RejmáneK, M., 2004: Plant invasions in Taiwan: insights from the flora of casual and naturalized alien species. Diversity and Distributions 10, 349-362. 
